Editorial

\title{
Foreword to the special volume 'Magmatic evolution of Mongolian part of the Central Asian Orogenic Belt and its geodynamic significance'
}

\author{
Karel SCHULMANN ${ }^{1,2^{*}}$, Ochir GEREL ${ }^{3}$, Wen Jiao XIAO ${ }^{4}$ \\ ${ }^{1}$ Czech Geological Survey, Klárov 3, 11821 Prague 1, Czech Republic; karel.schulmann@geology.cz \\ ${ }^{2}$ Ecole et Observatoire des Sciences de la Terre, Université de Strasbourg, UMR 7516 of CNRS, 1 rue Blessig, 67084 Strasbourg \\ Cedex, France \\ ${ }^{3}$ Mongolian University of Science and Technology, Baga Toiruu 34, Ulaanbaatar, Mongolia \\ ${ }^{4}$ State Key Laboratory of Lithospheric Evolution, Institute of Geology and Geophysics, Chinese Academy of Sciences, \\ Beijing 100029, China \\ * Corresponding author
}

The Central Asian Orogenic Belt (CAOB) represents a giant and emblematic accretionary orogen with longlasting evolution between 600 and $250 \mathrm{Ma}$ (Wilhem et al. 2012). This orogen was formed by accretion of Cambrian, Ordovician and Devono-Carboniferous arcs, back-arcs and accretionary wedges (Badarch et al. 2002; Windley et al. 2007) and Grenville-age microcontinents (RojasAgramonte et al. 2011) of both Siberian and Gondwanan affinities (Cocks and Torsvik 2007; Wilhem et al. 2012). The most puzzling is its mixed character, starting from purely Pacific-type accretionary system that developed progressively into collisional orogen of Tethysian type (Lehmann et al. 2010; Xiao and Santosh 2014). Magmatic evolution of such a transient geodynamic setting may provide pivotal insight into understanding of differences between Circum-Pacific accretionary and collisional processes and can be used as a proxy of purely juvenile crustal growth or subsequent recycling of assembled crust.

The crustal growth of the CAOB is supposed to having been extremely efficient and rapid and was characterized by voluminous "juvenile" granitic intrusions (Jahn et al. 2000). These magmatic additions had an episodic character with three Palaeozoic megacycles (Kovalenko et al. 2004) which were characterized by magmatic evolution of Gorny and Rudny Altai (Kruk et al. 2015). Here, Late Cambrian (512-495 Ma), Devonian (410-362 Ma) and Late Palaeozoic-Early Mesozoic (340-190 Ma) plutonic events were reported. Similar magmatic pulses were grossly recognized in the Mongolian tract of the $\mathrm{CAOB}$ as well but their precise age span and petrological and geochemical characteristics have been poorly constrained so far.

The present special issue of Journal of Geosciences is filling this gap by bringing together results of research of Mongolian, Czech, Russian, Japanese and Chinese au- thors who characterize magmatic evolution of significant part of SW Mongolia from Cambrian to Permian times.

The volume is organized according to the age and geochemical signature of magmatism which gradually evolved from arc-type Early Paleozoic calc-alkaline suites towards typical Late Carboniferous to Mesozoic intraplate alkaline granitoids.

The volume starts with two papers which characterize Early Palaeozoic magmatic evolution of the Mongolian Altai. The first contribution of Soejono et al. is entitled "Mid-Ordovician and Late Devonian magmatism in the Togtokhinshil Complex: new insight into the formation and accretionary evolution of the Lake Zone (western Mongolia)" (Fig. 1). This paper brings the first evidence of Mid-Ordovician (c. $460 \mathrm{Ma}$ ) magmatism characterized by various types of gabbros to diorites emplaced into the accretionary wedge possibly of Late Proterozoic age (the Lake Zone). Geochemistry of these rocks indicates the derivation of the gabbro-diorite suite exclusively from the mantle or in part from the juvenile mafic crust. The subsequent Late Devonian (c. $376 \mathrm{Ma}$ ) magmatism is characterized by intrusions of high-K calc-alkaline to shoshonitic granitoids into the rocks of both the gabbrodiorite suite and the accretionary wedge. The Mid-Ordovician magmatism is interpreted in context of the earliest Paleozoic magmatic-arc system intruding accretionary wedge of the Lake Zone. In contrast, the geochemical signature of the Late Devonian magmatism is viewed as inherited from the recycled arc-related crustal source during possible lithospheric thinning event.

The second paper by Hanžl et al. "Making continental crust: origin of Devonian orthogneisses from SE Mongolian Altai" provides new structural, geochemical and geochronological data for Devonian (380-370 Ma) orthogneiss and meta-rhyolite bodies from different crustal levels of the Tseel Terrane in the Mongolian Altai. The 

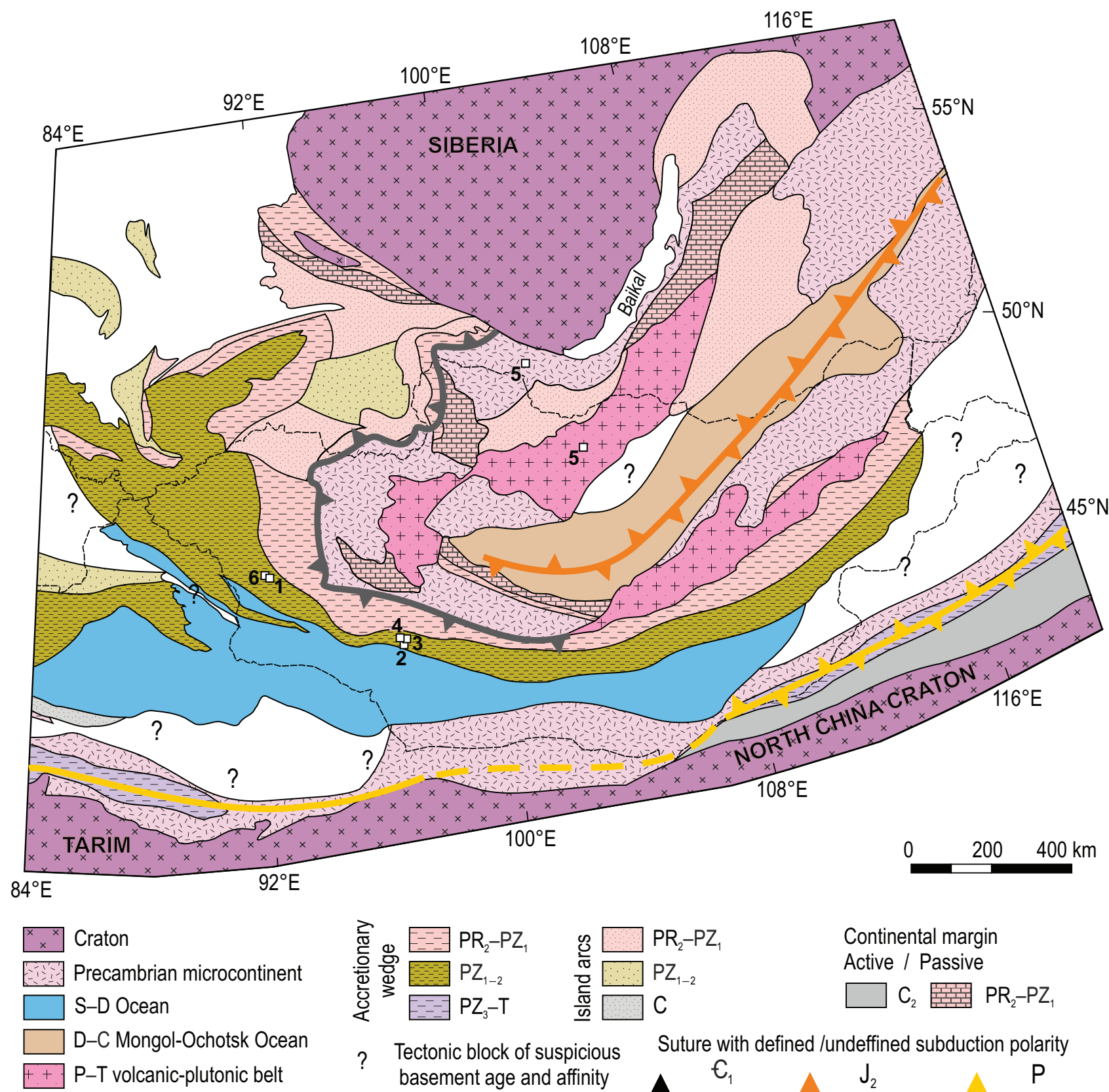

Continental margin
Active / Passive

$\mathrm{C}_{2}$ 監 $\mathrm{PR}_{2}-\mathrm{PZ}_{1}$

? Tectonic block of suspicious

Suture with defined /undeffined subduction polarity basement age and affinity

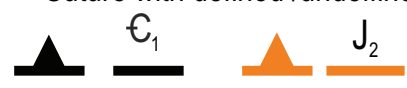

Fig. 1. Tectonic map of eastern part of the Central Asian Orogenic Belt compiled by Pavel Hanžl. Boxes show positions of areas described by six papers published in the volume. Box 1 - Cambrian and Late Devonian granitoids of the Lake Zone (Soejono et al.), Box 2 - Devonian orthogneisses of Tseel Terrane (Hanžl et al.), Box 3 - Devonian and Permian granitoids of the Mongol Altai Zone (Burenjargal et al.), Box 4 - Late Carboniferous Sagsai Pluton within the Mongol Altai Zone (Buriánek et al.), Box 5 - Early Permian alkaline rhyolite from the Mongol Altai Zone (Žáček et al.) and Box 6 - Late Carboniferous and Triassic rare-metal alkaline granitoids from the Mongol Okhotsk Belt (Antipin et al.). In this map the small terranes have been deliberately omitted to show the large-scale tectonic picture and respective positions of the three major magmatic groups: Cambrian arc magmatism - Box 1, Devonian arc and/or juvenile crust recycling - Boxes 2 and $\mathbf{3}$ and alkaline within-plate magmatism - Boxes 4-6.

high-K calc-alkaline chemistry and LILE over HFSE enrichments as well as mostly $0.8-0.9 \mathrm{Ga} \mathrm{Nd}$ and $\mathrm{Hf}$ crustal residence ages indicate that the orthogneisses originated by partial melting of Neoproterozoic to Cambrian magmatic arc-derived material and do not represent an old crystalline basement previously assumed in the Mongo- lian Altai (Fig. 1). It is proposed that a layered continental crust originated by syn-orogenic melting of youthful volcanosedimentary wedge during crustal-scale vertical shortening associated with lithospheric-scale extensional event. This mechanism may represent a viable model for cratonization of accretionary systems worldwide. 
The contribution of Burenjargaal et al. "Contrasting geochemical signatures of Devonian and Permian granitoids from the Tseel Terrane, SW Mongolia" compares chemistry and geochronology of previously studied Devonian and newly dated and analysed Permian (280-278 Ma) granitoid intrusions (Fig. 1). The chemistry of Devonian granitoids indicates an origin by melting of deep crust in the presence of slab-derived fluids and the magmas were emplaced at middle crustal levels, during regional HT-LP metamorphism. In contrast, the Permian intrusions solidified from a highly fractionated melt, probably in a shallow crust. The contrasting geochemical signatures of the Devonian and Permian granitoids reflect progressive maturing of the arc crust during protracted thermal evolution of the CAOB.

Manuscript of Buriánek et al. "Petrogenesis of the Late Carboniferous Sagsai Pluton in the SE Mongolian Altai" characterizes composite pluton intruding Tseel Terrane (Fig. 1). This intrusion consists mainly of amphibole gabbros (322 $\pm 2 \mathrm{Ma}, \mathrm{U}-\mathrm{Pb}$ zircon age) and syenites to quartz monzonites (307 $\pm 1 \mathrm{Ma}$ and $309 \pm 2 \mathrm{Ma}$ ) intruded by anatectic two-mica granites. Positive $\varepsilon_{H f}^{t}$ values of the quartz monzonites rule out participation of an old, mature crust in the source; highly positive $\varepsilon_{H f}^{t}$ values for monzogabbros imply exclusively a depleted mantle as a magma source. Three main stages in the Sagsai Pluton evolution were proposed: the gabbro started to grow at $>1000^{\circ} \mathrm{C}$ and $0.8-0.9 \mathrm{GPa}$, followed by mixing with crustal melts $\left(740-830^{\circ} \mathrm{C}, 0.5-0.6 \mathrm{GPa}\right)$ and final emplacement of quartz syenite $\left(600-670^{\circ} \mathrm{C}, 0.4-0.5 \mathrm{GPa}\right)$. The magmatic evolution of Sagsai Pluton confirms a model of deep lithosphere thermal anomaly associated with heterogeneous melting of crust in a post-subduction extensional regime, perhaps shortly after the slab break-off.

The paper by Žáček et al. "Astrophyllite-alkali amphibole rhyolite, an evidence of early Permian A-type alkaline volcanism in the western Mongolian Altai" brings geochemical data and a new K-Ar age of $299.9 \pm 9.1$ Ma from dyke of alkali rhyolite intruding volcanosedimentary sequence of Ordovician-Silurian age of the Hovd Terrane in western Mongolia (Fig. 1). The rhyolite contains blue alkali amphibole and astrophyllite, the latter with unusual, so far not yet reported highly ferroan composition. Geochemically, the rhyolite corresponds to a strongly fractionated alkaline (ferroan) magmatic rock. These data are interpreted in terms of Early Permian extension associated with the A-type alkaline volcanic activity.

Paper of Antipin et al. "Late Paleozoic and Early Mesozoic rare-metal granites in Central Mongolia and Baikal region: review of geochemistry, possible magma sources and related mineralization" deals with petrology and geochemistry of rare-metal $\mathrm{Li}-\mathrm{F}$ granites that occur in the large igneous provinces of the Mongol-Okhotsk
Belt (Fig. 1). The multiphase Late Paleozoic rare-metal plutons are composed of medium-grained biotite granites and leucogranites; the late phases are topaz-microclineand amazonite-albite-bearing. The Early Mesozoic intrusive activity was marked by the formation of giant magmatic zone with the Daurian-Khentei Batholith (230-190 Ma) in the central part of Mongol-Okhotsk Belt and rifting zones on its periphery characterized by alkaline and rare-metal granite plutons. These Mesozoic rare-metal $\mathrm{Li}-\mathrm{F}$ granites produced small domal intrusions of microcline-albite, amazonite-albite and albite-lepidolite granites. The geochemical data confirm that the genesis of rare-metal Li-F granites terminated with formation of albitite, microclinite and muscovite greisens. The isotope characteristics are in agreement with the model of formation of the initial granitic melts by partial melting of biotite-bearing granulites due to the rise of a mantle plume.

The presented collection of papers shows important and dynamic scientific activity of various research groups currently working in Mongolia. Recent progress in understating of magmatic activity shows evolution from primitive Ordovician arc magmatism, via Devonian re-melting of arc material-dominated crust to intraplate alkaline magmatism in Permian and Mesozoic. The presented works indicate that magmatic cycles can serve as important proxies of geodynamic evolution of $\mathrm{CAOB}$ accretionary system from Early Palaeozoic Pacific-type subduction to intraplate Late Palaeozoic to Mesozoic processes.

Acknowledgements. This special issue of Journal of Geosciences would be impossible without support of Czech National Foundation (GACR) project P210/12/2205 as well as the project of the Czech Development Agency "Geological mapping 1:50 000 and assessment of economic potential of selected region in Western Mongolia" CzDA-RO-MN-2013-1-32220. The volume benefited from continuous and enthusiastic support of our Mongolian and Chinese partners. We are grateful to all reviewers and to excellent editorial work of Journal of Geosciences staff who contributed to successfull completion of this volume.

\section{References}

Badarch G, Cunningham WD, Windley BF (2002) A new terrane subdivision for Mongolia: implications for the Phanerozoic crustal growth of Central Asia. J Asian Earth Sci 21: 87-110

Cocks LRM, Torsvik TH (2007) Siberia, the wandering northern terrane, and its changing geography through the Palaeozoic. Earth Sci Rev 82: 29-74 
JAHN BM, Wu FY, CHEN B (2000) Granitoids of the Central Asian Orogenic Belt and continental growth in the Phanerozoic. Trans Roy Soc Edinb, Earth Sci 91: 181-193

Kovalenko V, Yarmolyuk V, Kovach V, Kotov A, KozaKOV I, SAL'NiKOVA E, LARIN A (2004) Isotope provinces, mechanisms of generation and sources of the continental crust in the Central Asian mobile belt: geological and isotopic evidence. J Asian Earth Sci 23: 605-627

KRUK N (2015) Continental crust of Gorny Altai: stages of formation and evolution - indicative role of granitoids. Russ Geol Geophys 56: 1097-1113

Lehmann J, Schulmann K, Lexa O, Corsini M, Kröner A, Štípská P, Tomurhud D, Otgonbator D (2010) Structural constraints on the evolution of the Central Asian Orogenic Belt in SW Mongolia. Amer J Sci 310 : 575-628
Rojas-Agramonte Y, Kröner A, Demoux A, Xia X, Wang W, Donskaya T, Liu D, Sun M (2011) Detrital and xenocrystic zircon ages from Neoproterozoic to Palaeozoic arc terranes of Mongolia: significance for the origin of crustal fragments in the Central Asian Orogenic Belt. Gondwana Res 19: 751-763

Wilhem C, Windley BF, Stampfli GM (2012) The Altaids of Central Asia: a tectonic and evolutionary innovative review. Earth Sci Rev 113: 303-341

Windley BF, Alexeiev D, Xiao W, Kröner A, Badarch G (2007) Tectonic models for accretion of the Central Asian Orogenic Belt. J Geol Soc, London 164: 31-4

Xiao WJ, Santosh M (2014) The western Central Asian Orogenic Belt: a window to accretionary orogenesis and continental growth. Gondwana Res 25: 1429-1444 